\title{
The Effectiveness of Clinical Sterilization Methods in Dental Air/water Syringes
}

\author{
Seyoung Shin, Yeonmi Yang, Miah Kim, Jaegon Kim, Byeongju Baik \\ Department of Pediatric Dentistry and Institute of Oral Bioscience, School of Dentistry, Chonbuk National University
}

\begin{abstract}
This study aims to investigate contamination level and effective clinical disinfection methods of dental air/water syringes (AWS) by using microbial incubation. This study used AWS of ten dental unit chairs of Hospital.

Total 180 samples were obtained. There are six groups of samples: non-sterilized (group 1), sanitized with wet-gauze (group 2), sanitized with 78\% ethanol sponge for 10 seconds (group 3), sanitized with 78\% ethanol sponge for 20 seconds (group 4), sanitized with $1: 100$ diluted High Level Disinfectant ${ }^{\circledR}$ (group 5), autoclaved (group 6).

Group 1 and 2 showed statistically significant level of CFUs than Group 4, 5 and 6 ( $p<0.05$ ). Group 4, 5 and 6 did not show any noticeable CFU. Sanitizing AWS tips with ethanol and High level disinfectant ${ }^{\circledR}$ proves to be a useful and practical method for preventing cross-infections.
\end{abstract}

Key words : Dental air/water syringe, Sterilization methods, Microbial contamination

\section{I. 서 론}

최근 치과계의 주된 관심사 중 하나인 감염관리를 위해 ${ }^{1}$, 치 과진료실에서는 환자 간의 교차 감염과 환자와 의료인력 간의 교차 감염을 방지하기 위해 고도의 감염 조절이 요구 된다 ${ }^{2)}$.

치과에서 교차 감염은 환자 대 환자, 의료진 대 환자 뿐 아니 라 치료 중 사용되는 기구에 의해서도 가능하다. 적절하게 관리 되지 못한 기구의 사용은 병원균 전파의 원인이 될 수 있달. 2003년 미국질병통제예방센터(Centers for Disease Control and Prevention)의 치과 감염관리 지침에서는 치과에서 사용 되는 기구, 장치, 장비 등을 감염의 잠재적 위험도에 따라 위험 한(critical), 덜 위험한(semicritical), 위험하지 않은(nonsemicritical) category로 분류하였다. Air water syringe (AWS) tip은 덜 위험한 category로 분류되어 있으며, 이는 점 막이나 완전하지 않은 피부에 직접 닿지만 이를 통한 감염의 위 험성은 낮은 범주로 가압증기멸균을 시행하거나 FDA에서 승
인한 고도의 소독제를 이용한 소독을 시행해야 한다 ${ }^{4.5)}$. 가압증 기멸균을 실시하지 못한다면 일회용의 AWS tip의 사용이 타당 하다 ${ }^{6}$. 그러나, 매번 가압증기멸균한 AWS tip으로 교체하는 것은 쉽지 않고 비용과 구매의 문제로 일회용 tip의 사용도 어 려운 임상적인 문제점이 있다.

따라서 본 연구에서는 임상적으로 쉽게 이용가능한 알코올과 고준위 표면소독액 중 하나인 High level disinfectant ${ }^{\circledR}$ 를 AWS tip의 소독법의 효율성을 미생물 배양을 통해 비교 평가하였다.

\section{II. 연구 재료 및 방법}

1. 연구 재료

1) AWS tip

본 병원의 유니트 체어(Unit chair) 10대의 AWS tip을 대 상으로 하였다. 
2) 소독제

본 연구에 사용한 소독제는 $78 \%$ ethanol 스펀지와 1 : 100 으로 희석된 고준위 소독액 중 하나인 High level disinfectant ${ }^{\circledR}$ (New Genn, England)이다.

\section{2. 연구 방법}

연구에 사용된 미생물학적 검사법은 식품의약품안전처의 의 료기기의 제품상에 존재하는 미생물의 모집단 추정법에 관한 가이드라인을 기준으로 하였다 ${ }^{7)}$.

\section{1) 샘플 채취}

10대의 유니트 체어의 AWS tip은 오후 진료가 시작되기 전 에 가압증기멸균된 AWS tip으로 교체한 후 구강검진, 수복치 료, 교정 체크와 같은 일상적인 진료를 시행한 후 다음과 같은 방법으로 샘플을 채취 하였다. 1 군은 소독하지 않고 채취한 경 우, 2 군은 젖은 거즈를 이용하여 큰 오염물만 제거하고 채취한 경우, 3 군은 $78 \%$ 에탄올 스펀지로 10 초간 닦은 후 채취한 경 우, 4 군은 $78 \%$ 에탄올 스펀지로 20 초간 닦은 후 채취한 경우, 5 군은 1 : 100 으로 희석한 고준위 소독제를 적신 거즈로 20초 간 닦은 경우, 6 군은 가압증기멸균 후 채취한 경우이다(Table 1). 샘플의 채취는 멸균된 면봉을 PBS 용액에 적신 뒤 20초간 AWS tip을 닦아 채취하였다. 면봉 끝을 $1 \mathrm{~mL} \mathrm{PBS(phos-}$ phate-buffered saline) 용액이 들어있는 튜브에 잘라 넣었다. 샘플은 미생물의 배양을 위해 즉시 실험실로 옮겼다. 위와 같은

Table 1. Disinfection methods of each group

\begin{tabular}{ll}
\hline Group & \multicolumn{1}{c}{ Disinfection methods } \\
\hline Group 1 & Non-sterilized \\
Group 2 & Sanitized with wet-gauze \\
Group 3 & Sanitized with 78\% ethanol sponge for 10 seconds \\
Group 4 & Sanitized with 78\% ethanol sponge for 20 seconds \\
Group 5 & Sanitized with 1:100 diluted High level disinfectant ${ }^{\circledR}$ \\
Group 6 & Autoclaved \\
\hline
\end{tabular}

과정을 각각 6 개 군에 대해 실험을 3 번 반복하여 총 180 개의 샘플을 얻었다.

\section{2) 미생물 분석}

튜브 내 $1 \mathrm{~mL}$ 의 $\mathrm{PBS}$ 용액을 잘 섞은 후 $0.5 \mathrm{~mL} \mathrm{PBS} \mathrm{용액}$ 을 $\mathrm{BHI}$ 한천 평판 배지 (plate)에 골고루 뿌렸다. $\mathrm{BHI}$ 한천 배 지는 비선택적 배지로 다양한 박테리아, 이스트, 곰팡이 균을 배양시킬 수 있다. 평판 배지를 섭씨 $37^{\circ} \mathrm{C}$ 배양기에서 48 시간 동안 배양하였다. 평판배지에서 배양된 미생물 집락형성단위를 측정하였다(Fig. 1).

3) 자료분석

측정된 미생물 집락에 관한 자료는 윈도우용 $\mathrm{SPSS} 12.0$ version을 이용하여 통계적으로 분석하였다. 각 소독 방법간 차 이를 알아보기 위해 One way ANOVA, Tukey을 실시하였고, 유의수준은 0.05 를 기준으로 하였다.

\section{III. 연구 성적}

각 군에서 오염된 배지의 비율은 1 군, 2 군, 3 군에서 각각 $93.3 \%, 90.0 \%, 50.0 \%$ 의 plate에서 미생물 집락 형성을 보였 고, 4 군, 5 군, 6 군에서는 오염된 배지가 나타나지 않았다 (Table 2).

Table 2. Number of positive samples and rate of microbial cultivation plates of each group

\begin{tabular}{cccc}
\hline Group & $\begin{array}{c}\text { Number of } \\
\text { AWS tips }\end{array}$ & $\begin{array}{c}\text { Number of } \\
\text { positive samples (\%) }\end{array}$ & $\begin{array}{c}\text { Contamination } \\
\text { rate }\end{array}$ \\
\hline Group 1 & 30 & 28 & 93.3 \\
Group 2 & 30 & 27 & 90.0 \\
Group 3 & 30 & 15 & 50.0 \\
Group 4 & 30 & 0 & 0 \\
Group 5 & 30 & 0 & 0 \\
Group 6 & 30 & 0 & 0 \\
\hline
\end{tabular}

Contamination rate means the ration of plate which colony formed. AWS $=$ air water syringe
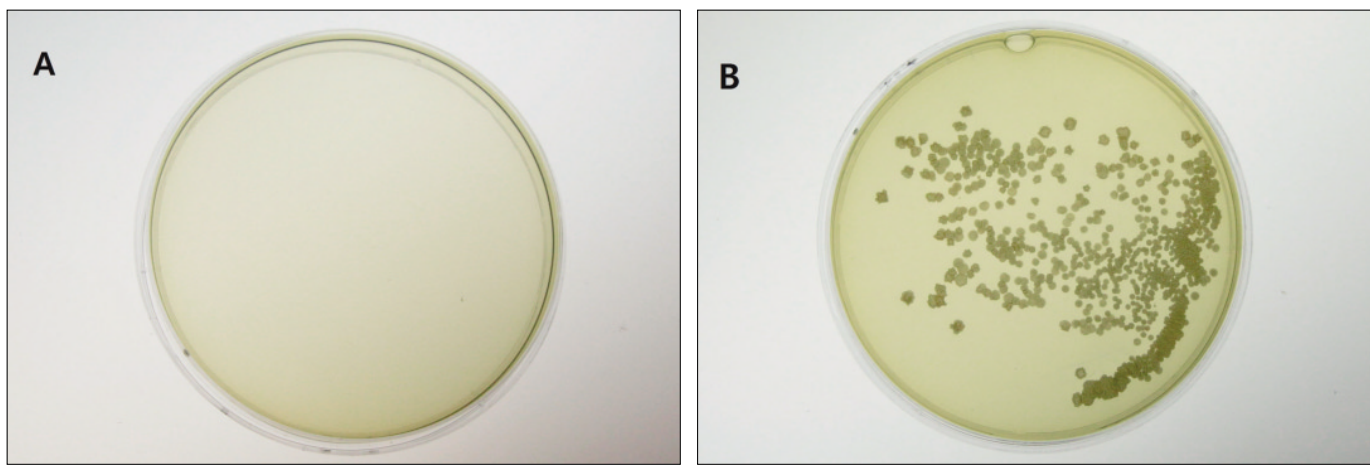

Fig. 1. (A) PBS was spread on BHI agar and incubated at $37^{\circ} \mathrm{C}$ for 48 hours. (B) Number of CFUs determined effectiveness of clinical sterilization. 
Table 3. CFUs of each group

\begin{tabular}{lccccc}
\hline Group & $\begin{array}{c}\text { Min. } \\
(\mathrm{CFU} /)\end{array}$ & $\begin{array}{c}\text { Max. } \\
(\mathrm{CFU} / \mathrm{ml})\end{array}$ & $\begin{array}{c}\text { Mean } \\
(\mathrm{CFU} / \mathrm{ml})\end{array}$ & SD & $p$-value \\
\hline Group 1 & 0 & 1703 & 184.4 & 328.0 & \\
Group 2 & 0 & 1509 & 143.3 & 295.5 & \\
Group 3 & 0 & 447 & 33.8 & 93.5 & \\
Group 4 & 0 & 0 & 0 & 0 & $<0.005^{*}$ \\
Group 5 & 0 & 0 & 0 & 0 & \\
Group 6 & 0 & 0 & 0 & 0 &
\end{tabular}

$\overline{\mathrm{CFU}}=$ colony forming unit, $\mathrm{SD}=$ standard deviation

Statistical analysis : ANOVA, ${ }^{*}: p<0.05$

각 군의 집락 형성단위(Colony Forming Unit; $\mathrm{CFU}$ )를 확 인한 결과 1 군, 2 군, 3 군에서는 미생물의 집락이 보였으나, 4 군, 5 군, 6 군에서는 미생물 집락이 나타나지 않았고, 통계적으 로 유의한 차이가 나타났다 $(p<0.05)$ (Table 3).

사후 검정으로 각 군 간의 차이를 비교한 결과 1 군은 3,4 , 5,6 군에 비해, 2 군은 $4,5,6$ 군에 비해 유의하게 높은 미생물 집락 형성 단위를 보였다 $(p<0.05)$. 1 군과 2 군, 2 군과 3 군은 유의할만한 차이를 보이지 않았다 $(p>0.05)$ (Table 4).

\section{IV. 총괄 및 고찰}

치과에서 감염을 일으킬 수 있는 바이러스와 박테리아는 다 양하며, 이러한 박테리아나 바이러스가 감염되는 경로는 의료 진, 다른 환자, 치과 치료시 표면, 치료시 사용되는 기구나 장비 를 통해서이다 ${ }^{3)}$. 치과에서 감염이 보고된 사례가 많지 않으나. 교차 감염을 중요하게 다루어야 하는 이유는 일부 혈액 매개 바 이러스는 감염 가능성이 높고, 감염시 치명적인 질환을 초래할 수 있으며, 치과에 내원하는 많은 환자들은 무증상인 경우 자신 이 감염성 질환을 않고 있는 것을 모르는 경우가 많아 감염균의 보균자인지를 판별하는 것이 불가능하기 때문이다. 치과에서 감염이 있었다고 보고된 증례는 선진국에서도 매우 드물고 개 발도상국에서는 인구의 상당수가 이러한 바이러스에 감염되어 있음에도 연구 자체가 전무하여 위험성이 저평가 되어 있다 ${ }^{8.9)}$.

최근 감염관리에 관한 인식이 높아짐에 따라 우리나라에서도 진료실에서 술자나 환자의 신체접촉을 통한 미생물 수를 감소 시켜 감염방지를 도모하기 위해 마스크의 착용, 보안경의 사용, 위생복, 모자, 방수처리된 에이프런과 같은 것을 사용 중이다 ${ }^{10)}$.

환자와 환자 사이의 감염을 방지하기 위해서는 진료장비와 부속기기들의 오염방지도 중요하다. 고속 핸드피스와 초음파 세척기는 분무 형태로 진료실내 공기를 오염시키며, 그 외의 일 반 기구도 타액과 혈액을 통한 전파경로가 된다 ${ }^{11.12)}$. 또한 진료 실 내의 다양한 표면들도 감염 전파경로가 되며 이러한 부위는 오염원으로 간과되기 쉽다. 치석제거와 같은 일반적인 치과치 료시 진료실 내에서 표면이 가장 많이 오염되는 부위를 조사한 결과 AWS tip, 환자의 턱받이, 컵을 두는 부위, 유니트 체어의 라이트 핸들 순이었다 ${ }^{13)}$. AWS 는 혈액과 타액이 닿을만한 작
Table 4. Statistical correlation between each group

\begin{tabular}{lcccccc}
\hline & Group & Group & Group & Group & Group & Group \\
& 1 & 2 & 3 & 4 & 5 & 6 \\
\hline Group 1 & - & - & - & - & - & - \\
Group 2 & 0.954 & - & - & - & - & - \\
Group 3 & $0.022^{*}$ & 0.199 & - & - & - & - \\
Group 4 & $0.002 *$ & $0.035^{*}$ & 0.980 & - & - & - \\
Group 5 & $0.002^{*}$ & $0.035^{*}$ & 0.980 & 1.000 & - & - \\
Group 6 & $0.002^{*}$ & $0.035^{*}$ & 0.980 & 1.000 & 1.000 & - \\
\hline Statistical analysis : Tukey, ${ }^{*}: p<0.05$ & & &
\end{tabular}

업장에 포함되고, 감염이 일어날 수 있는 가능성이 높은 부분이 기도 하다. AWS tip은 일상적인 진료시에도 표면이 점막과 접 촉되고, 내부는 유니트 체어 수관(dental unit waterline)과 연결되어 미생물이 포함된 물이 통과하며, 타액이나 혈액이 흡 인될 가능성이 있다. 따라서 각 환자간 치료 후에는 교차감염의 예방을 위한 적절한 관리가 필요하다. 그러나 국내에서는 이러 한 연구에 대한 보고가 거의 없는 상황이다.

Merchant와 Molinari1 ${ }^{14)}$ 는 일상적인 치과치료 후 AWS tip 을 분리하여 가압증기멸균한 경우 어떠한 미생물도 남아있지 않으므로 타당한 방법이라고 하였고, Pttaiah 등6)은 가압증기 멸균시에도 tip 내부를 완전히 세척할 수 없기 때문에 일회용 tip의 사용을 주장하였다. 여분의 AWS tip이 구비되어 있지 않 으면 AWS tip의 가압증기멸균을 매번 하여 교체하는 것은 어 려우며, 빈번한 열소독시 내부 부품의 피로도 증가, AWS tip의 잦은 분리 및 조립시 연결부의 나사나 베어링 손상으로 유니트 체어 수명 자체가 단축될 수 있다.6) 일회용 tip을 사용하는 경 우가 대안이나 이는 구매의 어려움, 비용의 증가, 폐기물 증가 와 처리비용의 문제도 발생한다. 따라서 본 연구에서는 임상적 인 상황에서 쉽고 빠르며 효과적으로 AWS tip의 미생물을 감 소시킬 수 있는 방법을 진료실에서 가장 흔히 사용하는 소독제 를 이용하여 연구하였다. 10초간 알코올 스펀지를 이용하여 tip 을 닦는 것만으로도 소독하지 않은 군에 비해 미생물 수가 유의 하게 감소하였고, 20 초간 알코올 스펀지나 $1: 100$ 으로 희석시 킨 고준위 소독제를 적신 거즈로 AWS tip을 닦은 경우에는 가 압증기멸균한 경우와 같이 미생물이 배양되지 않았다. 그러나 본 연구에서 미생물 불검출이 멸균과 같은 상태를 의미하지는 않는다. 본 연구에서 선택한 $\mathrm{BHI}$ 배지가 모든 종류의 미생물을 배양할 수는 없으며, 미생물 채취시 면봉법을 이용하는 경우 면 봉을 조작하는 방법이 매번 달라지기 때문에 오류가 일어날 수 있고, 표본에 있는 모든 미생물 개체를 면봉으로 수집하기란 거 의 불가능하며, 수집된 미생물 개체 중 일부는 면봉 자체의 기 질 내에 숨어들기 때문에 검출이 어렵다는 한계점이 있닥. 따 라서 본 연구에서 사용한 소독법으로 미생물이 검출되지 않았 다 하더라도 면역력이 억제된 환자나 어린이의 경우에는 감염 관리 측면에서 가압증기멸균을 하거나 일회용 AWS tip을 사용 해야 한다. 
치과에서 사용되는 모든 기구와 장비들은 멸균(sterilization)이 되어 있어야 한다. 그러나 치과용 진료의자에 달려 있 는 기구거치대와 같은 일부 장비나 표면은 멸균하기 힘들기 때 문에 잘 소독(disinfection)하는 것이 필요하다. 쉽게 이용 가능 한 소독액으로 알코올, 알데히드, Bisguanides, 할로겐 화합 물, 페놀 등의 소독액이 대표적으로 많이 사용되며 이는 기구의 특성을 고려하여 사용해야 한다 ${ }^{15}$.

본 연구에서 사용한 알코올과 고준위 소독제는 임상적으로 가장 쉽게 이용할 수 있고, 대부분의 진료실에서 쉽게 구비가 가능하여 이를 선택하여 사용하였다. 특히, 알코올은 치과 진료 실에서 가장 쉽게 이용이 가능하며, 금속기구를 부식시키지 않 고, 결핵균을 포함한 다양한 종속영양 박테리아, 바이러스, 균 류(fungi)를 죽일 수 있다. 포자는 완전히 불활화 시킬 수는 없 고 포자생식(sporation)과 발아(germination)를 늦출 수는 있 다 ${ }^{16)}$. 에탄올은 $50 \%$ 이하의 농도에서는 박테리아를 죽이는 (cidal) 능력이 현저히 떨어지며, 60 90\% 농도에서 최적의 살균능력을 보인다 ${ }^{17)}$. 국내에서 시판되는 대부분의 알코올 스펀 지는 70 78\% 수준이며, 본 연구에서는 이 중 1종을 선택하여 사용하였다. 연구에 사용한 또 다른 고준위 소독제인 High Level Disinfectant ${ }^{\circledR}$ (New Genn, England)는 4급 암모늄과 자체 개발된 특허물질의 혼합물로 세균의 세포벽에 필수 원소 를 제거하여 단백질을 변성시켜 파괴시키며, 음이온, 양이온, 비이온성 및 금속이온이 존재하여도 살균력에는 영향을 받지 않아 세균과 결핵균 및 포자균에서도 살균력을 발휘한다. 1 : 100 으로 물에 희석하여 손소독, 의료기구, 치과기구의 고준위 소독을 할 수 있다 ${ }^{18)}$. 10 초간 알코올 스펀지를 이용해 표면을 닦은 결과 미생물은 유의하게 감소하였으나 채취한 샘플의 절 반에서 미생물이 검출되었고, 20 초간 알코올 스펀지와 고준위 소독제를 적용하는 경우에는 눈에 띄는 미생물의 검출이 없었 으므로, 이러한 소독제를 20초 이상 적용하는 경우 AWS tip을 통한 감염을 방지할 수 있을 것이다.

본 연구는 임상에서 가장 쉽게 이용이 가능한 소독액 2 가지 를 AWS tip에 적용하여 BHI 배지에 배양하였다. 또 샘플을 채 취하기 전 구강검진, 수복치료, 교정체크와 같은 일상적인 치료 를 진행하였으나 환자의 수, 진료내용의 표준화가 부족하였다. 따라서 추가적인 연구에서는 표준화된 지침에 따라 샘플을 채 취하여 다양한 소독방법으로 AWS tip 내부의 오염을 제거할 수 있는 방안을 찾고, 선택적 배지를 이용하여 Legionella 종이 나 Pseudomonas aerusinosa와 같은 실제 병원성이 있는 균 주에 관한 연구도 추가적으로 시행하며, 샘플을 채취할 때의 표 준화된 지침이 필요할 것으로 사료된다.

국내 치의학은 지난 수십년간 비약적으로 발전하여 높은 진 료수준을 보이고 있다. 그러나 감염관리, 교차감염의 예방 측면 에서는 그 인식과 실천이 부족하며, 이에 관한 연구도 거의 찾 을 수 없다. 대한치과의사협회에서는 최근 미국과 유럽의 기준 을 바탕으로 치과의료기관 감염관리 프로그램을 제시하여 우리 나라에서도 체계적인 감염관리가 이루어질 수 있는 지침을 제 공하고 있다 ${ }^{19}$. 이러한 지침이 지켜지기 위해서는 치과의사 개
인이 감염관리 지침을 잘 알고 있으며, 진료실 인력에게 적절한 교육을 제공해야 하고, 일회용 제품의 사용에 따른 적절한 수가 보상과 같은 현실적인 문제도 해결되어야 할 것이다.

\section{IV. 결 론}

AWS tip을 통한 교차감염을 줄이기 위해 진료실에서 흔히 사용되는 소독제를 이용하여 쉽고 빠르게 AWS tip의 미생물을 효과적으로 감소시키는 방법을 연구하였다. 그 결과 AWS tip 에 알코올과 고준위 표면소독제를 20 초 이상 적용한 경우에는 소독하지 않은 경우, 젖은 거즈로 큰 오염물만 제거한 경우, 10 초간 알코올 스펀지로 소독한 경우보다 미생물의 수가 유의하 게 감소하였고, 가압증기멸균한 경우와 같이 모든 평판배지에 서 미생물이 배양되지 않았다. 따라서 기저질환이 없는 환자에 게 비침습적인 술식을 할 때에는 알코올이나 승인받은 고준위 표면소독제를 사용할 수 있을 것이다. 그러나 알코올계 소독제 나 High level disinfectant ${ }^{\circledR}$ 소독제는 포자를 불활성화 시킬 수 없고 미생물의 불검출이 멸균과 같은 상태를 의미하지는 않 으므로 면역이 억제된 환자, 어린이, 침습적 술식을 시행할 때 에는 더 철저한 감염관리가 필요하므로, AWS tip을 가열멸균 하거나 일회용의 사용이 필요하다고 생각된다.

\section{References}

1. Cellini L, Campli E, Candia M, Chiavaroli G : Quantitative microbial monitoring in a dental office. Public Health, 115:301-305, 2001.

2. Chang HS, Lee SR, Hong SO, Min KS, et al. : Effect on infection control barrier thickness on light curing units. J Kor Acad Cons Dent, 35:368-373, 2010

3. Laheij A, Kistler J , Belibasakis G, Soet J, et al. : Healthcare-associated viral and bacterial infections in dentistry. J Oral microbiol, 4:17659-17668, 2012.

4. Guidelines for Infection Control in Dental HealthCare Settings 2003. Available from URL: http:// www.cdc.gov/mmwr/preview/mmwrhtml/rr5217a1.h tm (assessed on July 7, 2013)

5. Guidelines for Environmental Infection Control in Health-Care Facilities. Available from URL: http://www.cdc.gov/mmwr/preview/mmwrhtml/rr52 10a1.htm (assessed on July 7, 2013)

6. Raghunath P, James C, Afashin A, Jodi T : Rationale for using single use disposable air/water syringe tips. Compend Contin Educ Dent, 20:10561058, 1999.

7. KFDA- sterilization-11737-1, 2006 : Available from URL:http://www.prism.go.kr/homepage/researchCo 
mmon/retrieveResearchDetailPopup.do?research_id =1470000-200700020 (assessed on September 20, 2013)

8. Elise B, Ian W, Craig S, Mary C : Risk and management of blood-borne infections in health care workers. Clin Microbiol Rev, 13:385-407, 2000

9. Jane P, Richard P, Janine Jagger : Infected health care workers and patient safety: A double standard. Am J Infect Control, 34:313-319, 2006.

10. Hwang BN : An anti cross infection protocol in dentistry, The $J$ of the Kor Dent Assoc, 31:897-904, 1993.

11. Legnani P, Checchi L, Pelliccioni GA, D’Achille C : Atmospheric contamination during dental procedures. Quunterssence Int, 25:435-439, 1994.

12. Osorio R, Toledano M, Liébana J, Lozano JA, et al. : Environmental microbial contamination. Pilot study in a dental surgery. Int Dent J, 45:352-357, 1995.

13. McColl E, Bagg J, Winning S : The detection of blood on dental surgery surfaces and equipment following dental hygiene treatment, $B r$ Dent J, 176:
65-67, 1994.

14. Virginia M, John M : Study on adequacy of sterilization of air-water syringe tips. Clin Prev Dent, 13: 20-22,1991.

15. Lakeshman S : Essential Microbiology for Dentistry. Churchill Livingstone, Edinburgh, 314-328, 2007.

16. Gerald M, Denver R : Antiseptics and Disinfectants: Activity, action, and resistance. Clin Microbiol Rev, 12:147-179 1999.

17. Guideline for Disinfection and Sterilization in Healthcare Facilities, 2008. Available from URL: http://www.cdc.gov/hicpac/pdf/guidelines/Disinfecti on_Nov_2008.pdf (assesed on October 12, 2013)

18. NewGenn High Level Disinfectant. Available from URL: http://www.newgenn.us/High\%20Level\%20 Disinfectant\%20020307.pdf (assessed on September 20, 2013)

19. Infection control procedures in dental office. Available from URL: http://www.kda.or.kr/kda/ KDAShare/kdamba_ebook/ecatalog.html? Dir = (assessed on September 20, 2013) 
국문초록

\title{
임상적으로 유용한 치과용 Air/water syringe의 소독법
}

\author{
신세영 · 양연미·김미아 · 김재곤 · 백병주
}

전북대학교 치의학 전문대학원 소아치과학교실 및 구강생체과학연구소

본 연구는 미생물의 배양을 통해 임상적으로 효과적인 air/water syringe의 소독법을 조사할 목적으로, 치과 병원에서 사 용하는 10 개의 AWS tip을 사용하였다.

실험군은 6 개 군으로 나누어 실험을 3 번씩 반복하여 180 개의 샘플을 얻었다. 1 군은 소독하지 않은 경우, 2 군은 물에 적신 거즈로 큰 오염물만 제거한 경우, 3 군은 $78 \%$ 에탄올 스편지로 10 초간 소독한 경우, 4 군은 $78 \%$ 에탄올 스펀지로 20 초간 소 독한 경우, 5 군은 $1: 100$ 으로 희석한 High Level Disinfectant ${ }^{\circledR}$ 을 적신 스펀지로 20 초간 소독한 경우, 6 군은 가압증기멸 균한 경우이다.

1 군과 2 군은 $4,5,6$ 군보다 유의하게 높은 미생물집락형성을 보였다 $(p<0.05)$. 또한 $4,5,6$ 군은 미생물 집락이 나타나 지 않았다.

에탄올과 High level disinfectant ${ }^{\circledR}$ 를 사용하여 AWS tip을 20초 이상 소독하는 것은 가압멸균법이나 일회용 tip의 사용 이 가능하지 않은 경우 교차감염 예방을 위해 유용한 방법이 될 수 있다.

주요어: 치과용 air/water syringe, 소독법, 미생물 오염 